\title{
Erythrocyte Glucose-6-phosphate Dehydrogenase Activity in Klinefelter's Syndrome
}

\author{
By \\ Keiya Tada and Tadashi Hayashi \\ From the Department of Pediatrics, Faculty of Medicine, Tohoku \\ University, Sendai; Director: Prof. Ts. Arakawa \\ (Received for publication, December 17, 1964)

\begin{abstract}
Glucose-6-phosphate dehydrogenase (G6PD) in erythrocyte was determined in two patients with Klinefelter's syndrome. It showed a significantly higher activity, especially in a patient of XXXXY type of the syndrome, than normal range. This result suggests that an excess of genetic material from the $X$ chromosome is responsbile for higher activity of the erythrocyte G6PD in Klinefelter's syndrome.
\end{abstract}

It is well known that primaquine sensitivity due to deficiency in glucose6-phosphate dehydrogenase (G6PD) in erythrocyte is genetically transmitted by sex-linked trait.1-7 Therefore, it is reasonable to presume that the gene controlling G6PD activity in erythrocyte locates on the $\mathrm{X}$ chromosome. On the other hand, Klinefelter's syndrome is characterized by the existence of extra $\mathrm{X}$ chromosomes in the chromosomal constitution.

It is quite interesting to investigate G6PD activity in erythrocyte from the patients with Klinefelter's syndrome in a viewpoint of correlation between the gene and the chromosome.

\section{METHOD AND MATERIALS}

Case I, a 20 month-old boy, showed clinical signs of hypogenitalism, skeletal abnormalities and retardation of mental and physical development. Chromosomal analysis revealed XXXXY type of Klinefelter's syndrome (cf. Fig. 1). Detailed report of the case will be described elsewhere.

Case II, a 15 year-old boy, showed clinically mental retardation and delay of secondary sexual characters. Chromosomal analysis revealed XXY type of Klinefelter's syndrome (cf. Fig. 2).

Hematologically neither anemia nor reticulocytosis was found in both patients.

Erythrocyte G6PD activity was measured by a slight modification of Zink-

多田鳘也，林＼cjkstart正 
Erythrocyte Glucose-6-phosphate Dehydrogenase Activity in Klinefelter's Syndrome 249

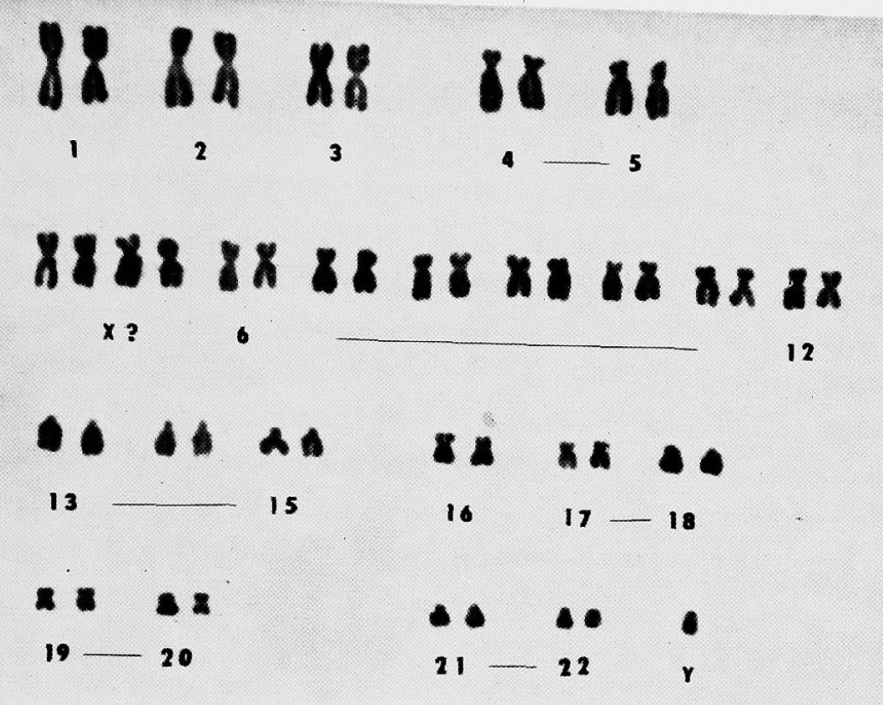

Fig. 1. Karyotype of chromosomes from the patient of Case I (XXXXY type).

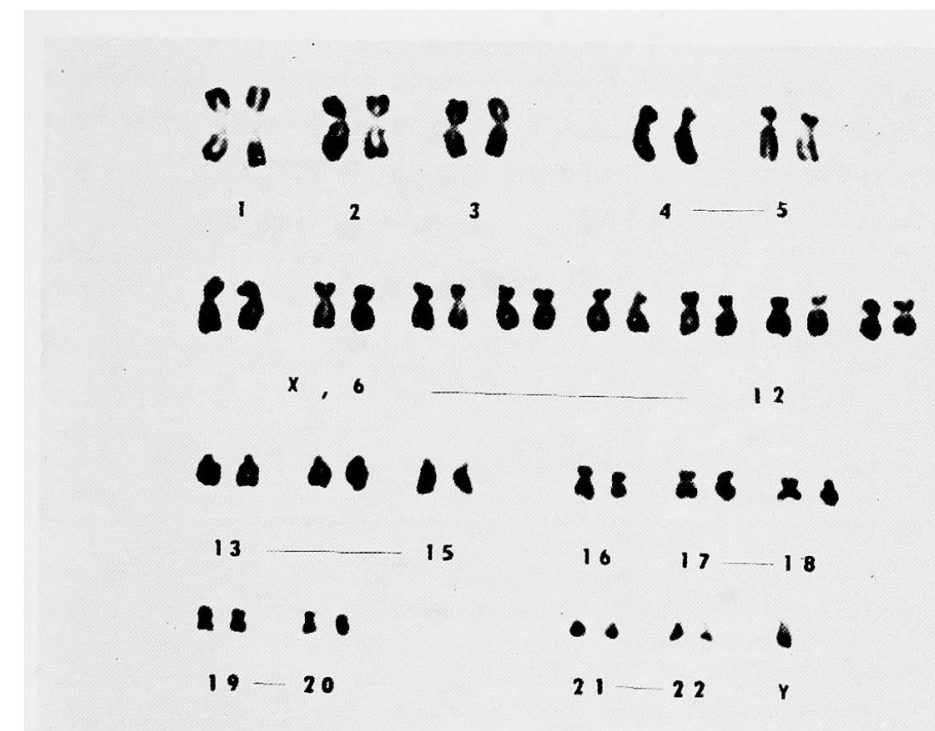

Fig. 2. Karyotype of chromosomes from the patient of Case II (XXY type).

ham et al.'s method as follows. The heparinized blood specimen was immediately centrifuged in the cold at 3000 r.p.m. for 10 minutes. The supernatant plasma and white cell layer were aspirated off, and the remaining red cells were washed three times in the cold with a chilled solution of $0.14 \mathrm{M}$ sodium chloride. Most of 
the saline was removed and $0.2 \mathrm{ml}$ of packed red cells was added to $3.8 \mathrm{ml}$ of distilled water. The red cell suspension was left stand at room temperature for 10 minutes. The resulting hemolysate was centrifuged in the cold at 3,000 r.p.m. for 10 minutes, and the supernatant was used for the assay.

The assay system consisted of $0.2 \mathrm{ml}$ of the hemolysate, $0.2 \mathrm{ml}$ of $0.03 \mathrm{M}$ $\mathrm{MgCl}_{2}(\mathrm{pH} 7.0), 2.0 \mathrm{ml}$ of $0.19 \mathrm{M}$ Tris buffer $(\mathrm{pH} 8.0), 0.2 \mathrm{ml}$ of $0.02 \mathrm{M}$ dipotassium glucose-6-phosphate ( $\mathrm{pH} 7.0), 0.4 \mathrm{ml}$ of $0.002 \mathrm{M} \mathrm{TPN}(\mathrm{pH} 6.8)$, and $3.0 \mathrm{ml}$ of water. The blank solution contained all of these reagents except TPN and G6P. The incubation was made at $37^{\circ} \mathrm{C}$ for exactly 15 minutes after the reaction was started by the addition of TPN. The optical density was read at $340 \mathrm{~m} \mu$ by spectrophotometer before and after the incubation. The increment in the optical density was found to be linear during the reaction time from 0 to 20 minutes. The enzyme activity was expressed as the increment in optical density per minute per $\mathrm{ml}$ of red cells.

Erythrocyte aldolase activity was cetermined by the method of Sibley and Lehninger. ${ }^{9,10}$

\section{RESULTS}

Table I showed the results of G6PD and aldolase activities in erythrocytes from the patients with Klinefelter's syndrome.

The patient of Case I (XXXXY type) showed a significantly high activity of G6PD and the patient of Case II (XXY type) was of upper limit value of the normal range. On the other hand, erythrocyte aldolase activity was found to be within normal limits ${ }^{10}$ in both patients.

\section{DISCUSSION}

The problem of gene locus on the chromosome has recently taken an increasing interest. The work in this field seemed to be confined to Down's syndrome.

Table I. Glucose-6-phosphate Dehydrogenase and Aldolase Activities in Erythrocytes from the Patients with Klinefelter's Syndrome

\begin{tabular}{l|c|c}
\hline & $\begin{array}{c}\text { Glucose-6-Phosphate } \\
\text { dehydrogenase } \\
\text { units/ml of red cells }\end{array}$ & $\begin{array}{c}\text { Aldolase } \\
\text { units/ml of red cells }\end{array}$ \\
\hline Case I, XXXXY type & 3.52 & 830 \\
& 3.28 & \\
Case II, XXY type & 3.60 & 685 \\
& 2.76 & \\
Normal value & 2.58 & 727 \\
Average & 2.10 & $408-1170$
\end{tabular}

Note: G6PD activity was determined repeatedly on different occasions in the patients. 
Up to date, two valuable informations are obtained concerning gene locus on the chromosome no. 21. The evidence, that leukocyte alkaline phosphatase activity is diminished in chronic myelogenous leukemia ${ }^{11-13}$ which is characterized by a minute chromosome ( $\mathrm{Ph}$ ' chromosome) presumed to be from no. 21 and that it is increased in Down's syndrome ${ }^{14-17}$ which shows the trisomy no. 21 , suggests the gene controlling leukocyte alkaline phosphatase activity on the chromosome no. 21. Another evidence of a locus concerned with the production of the enzyme galactose-1-phosphate uridyl transferase on the chromosome no. 21 has been reported by Brandt et al. ${ }^{18,19}$

The present results have revealed that two patients with Klinefelter's syndrome who possess the extra $\mathrm{X}$ chromosomes have a higher activity of erythrocyte G6PD, especially in Case I of XXXXY type. Since G6PD deficient hemolytic anemia is known to be transmitted by sex-linked trait, the gene controlling the activity of erythrocyte G6PD should be located on the $\mathrm{X}$ chromosome. Therefore, it is presumed that an excess of genetic material from the $\mathrm{X}$ chromosome may be responsible for higher activity of erythrocyte G6PD in Klinefelter's syndrome.

\section{Literature}

1) Browne, E.A. Bull. Johns Hopk. Hosp., 1957, 101, 115.

2) Childs, B., Zinkham, W., Browne, E.A., Kimbro, E.L. \& Torbert, J. V. ibid., $1958,102,21$.

3) Gross, R.T., Hurwitz, R.E. \& Marks, P.A. J. clin. Invest., 1958, 37, 1176.

4) Szeinberg, A., Sheba, C. \& Adams, A. Blood, 1958, 13, 1043.

5) Larriza, P., Brunett, P. \& Grignani, F. Arch. Haenat., 1960, 45, 129.

6) Adam, A. Nature, 1961, 189, 686.

7) Tarlov, A.R., Brewer, G.J., Carson, P.E. \& Alving, A.S. Arch. intern. Med., 1962, 109, 209.

8) Zinkham, W.H., Lenhard, R.E. \& Childs, B. Bull. Johns Hopk. Hosp., 1958, 102, 169.

9) Sibley, J.A. \& Lehninger, A. J. biol. Chem., 1949, 177, 859.

10) Watanabe, Y. Tohoku Igaku Zassi (Jap.), 1962, 65, 255.

11) Wiltshaw, E. \& Moloney, W.C. Blood, 1955, 10, 1120.

12) Valentine, W.N. \& Beck, W.S. J. lab. clin. Med., 1951, 1, 39.

13) Tanaka, K.R., Valentine, W.N. \& Fredricks, R.E. New Eng. J. Med., 1960, 262, 912.

14) Alter, A.A., Lee, S.L., Pourfar, M. \& Dobkin, G. J. clin. Invest., 1962, 41, 1341.

15) Alter, A.A., Lee, S.L., Pourfar, M. \& Dobkin, G. Blood., 1963, 22, 165.

16) Trubowitz, S., Kirman, D. \& Masek, B. Lancet, 1962, 2, 486.

17) O'Sullivan, M.A. \& Pryles, C.V. New Eng.J. Med., 1963, 268, 1168.

18) Brandt, N.J. Lancet, 1962, 2, 837.

19) Brandt, N.J., Frgland, A., Mikkelsen, M., Nielsen, A. \& Tolstrup, N. ibid., 1963, 2, 700 . 